\title{
The Influence of Fertilizer Systems on the Content of Various Forms of Potassium and Nutrition Mode of Humus
}

\author{
ALEKSANDR NICOLAEVICH ESAULKO, YLIA IVANOVNA GRECHISHKINA, \\ MAKSIM SERGEEVICH SIGIDA, SERGEI ALEKSANDROVICH KOROSTILEV, \\ and EVGENIY VALERIVICH GOLOSNOI
}

Stavropol State Agrarian University, Russia, 355017, Stavropol, 12 Zootechnicheskiy Ln.

http://dx.doi.org/10.13005/ojc/320642

(Received: November 25, 2016; Accepted: December 12, 2016)

\begin{abstract}
The identification of potential soil reserves of potassium available for plants, their predictive assessment, determination of influence of intensity of potassium balance on the yield of major crops and the content of forms of element in the soil is particularly important, which was the basis for the study of the influence of the most common systems of fertilizers on the agrochemical properties of the soil, the peculiarities of changes in the potassium fund of leached humus, the growth and development of corn silage, which indicates the relevance of norms, combinations and forms of fertilizer for specific soil and climatic conditions of maize cultivation.
\end{abstract}

Keywords: Forms of potassium, Nitrate nitrogen, Mobile phosphorus, Exchange potassium, Leached humus, Fertilizer system, Soil properties, Nutritional regime of the soil.

\section{INTRODUCTION}

The level of soil fertility is a decisive factor in obtaining of high and stable yields of agricultural crops. With the influence of fertilizers in the arable layer of soil increases the content of mobile forms of nitrogen, phosphorus and potassium. This provides an opportunity to improve natural soil productivity and crop yields ${ }^{5}$. The presence of relatively large reserves of soil potassium and, consequently, the absence of a noticeable positive effect from the intake of potash fertilizers, as a rule, in short-term studies, explains the fact that among the major plant nutrients (nitrogen, phosphorus, potassium) less attention is paid for potassium.

The purpose of the research was to study the influence of fertilizer systems on the content of potassium forms in the meter profile of leached humus, nutrition regime during the growing season and the productivity of corn silage.

The objectives of the research were to assess the impact of the applied system of fertilizers 
on the basic agrochemical indicators; to study the content of potassium forms in the meter profile of leached humus in connection with systematic application of fertilizers; to study the productivity of green mass of corn. The studies conducted on the leached humus of Stavropol upland allowed to recommend for the production the most effective dose of fertilizers for corn silage in the composition of biologizing and settlement systems of fertilizers in crop rotation. Doses of nitrogen-potassium fertilizers in conducting the 1st inter-row cultivation of maize for silage were offered to the production depending on the background food. For the first time in the zone of moderate moistening of the Stavropol upland on the leached humus was studied the influence of various fertilizer systems on the nutritional mode, on the content of potassium forms in the soil and the productivity of corn silage.

\section{Technique}

Studies were conducted on the base of departments of agricultural chemistry and agriculture experimental station of the Stavropol state agrarian University in a typical grain crop rotation (lea occupied (peas+oats), winter wheat, winter barley, silage maize, winter wheat, peas, winter wheat, spring rape), which is an embodiment of a long experience "Theoretical and technological bases of biogeochemical matter fluxes in agricultural landscapes", registered in the register of certificates of lengthy experiments Geosite VNIIA, Russian Federation.

The soil of the experimental plot - leached black earth, powerful, less humus and heavy loam. The humus content in the $0-20 \mathrm{~cm}$ soil layer of the experimental plot is equal to $5,2-5,9 \%$. The content of mobile phosphorus is the average $(18-28 \mathrm{mg} / \mathrm{kg}$ according to Machigin), the content of exchangeable potassium - is high (240-290 mg/kg of soil), and the reaction of the soil solution is neutral $(6.1$ to 6,7$)$.

The climate of the area of the experiments is characterized as continental, with moderate hydration (the climate-hydrothermal coefficient is 1.1 to 1.3). Perennial average rainfall is of $623 \mathrm{~mm}$. Sum of active temperatures is $2800-3200^{\circ} \tilde{N}$. The average annual air temperature is $+9.2^{\circ} \mathrm{C}$.
Weather conditions in the years of the experiments were characterized with the adverse moisture conditions due to high temperature, especially in the vegetation period of maize.

Relative to the control (without fertilizers) in the experiment were studied three systems of fertilizers:

1) recommended - with the intensity of crop rotation $115 \mathrm{NPK} \mathrm{kg} / \mathrm{ha}$ including $\mathrm{N}_{50} \mathrm{P}_{59} \mathrm{~K}_{6}$ with a ratio of $\mathrm{N}: P: K=1: 1,18: 0,13+5 \mathrm{t} / \mathrm{ha}$ of manure;

2) biologizing - with the intensity of a crop rotation NPK $63 \mathrm{~kg} \mathrm{NPK} / \mathrm{ha}$, including $\mathrm{N}_{43} \mathrm{P}_{20} \mathrm{~K}_{0}$ with a ratio of $\mathrm{N}: \mathrm{P}: \mathrm{K}=1: 0,47: 0+8.2 \mathrm{t} / \mathrm{ha}$ of organic fertilizer, 5 t/ha of manure litter;

3) estimating - with a saturation of 1 hectare - 167 $\mathrm{kg} / \mathrm{ha}$ of NPK including $\mathrm{N}_{80} \mathrm{P}_{78} \mathrm{~K}_{9}$ with a ratio of N:P:K $=1: 0,98: 0,12+5 \mathrm{t} /$ ha of manure.

Directly under the corn with the previously used plowing method of soil treatment to a depth of $20-22 \mathrm{~cm}$ relative to the control, were applied the following doses of fertilizers in accordance with the scheme experience: 1) manure 20 t/ha $+N_{30} P_{80}+N_{10} P_{10}$ (at sowing); 2) manure $20 \mathrm{t} /$ ha $5.4 \mathrm{t} / \mathrm{ha}$ organic fertilizer $+\mathrm{N}_{10} \mathrm{P}_{10}$ (at sowing);

3) manure $20 \mathrm{t} / \mathrm{ha}+\mathrm{N}_{52} \mathrm{P}_{70} \mathrm{~K}_{30}+\mathrm{N}_{10} \oplus_{10}$ (at sowing).

Placement of variants was made according to the method of split plots.

The total area of the plot is $108 \mathrm{~m}^{2}$, width $7.2 \mathrm{~m}$, length $-15 \mathrm{~m}$, an estimated area $-50 \mathrm{~m}^{2}$. The experiment was repeated three times, bunk location of plots, dislocation of repetitions is solid.

Field experiments were accompanied by the following tests, surveys and observations: phenological observations; the accumulation of dry biomass and crop structure according to the method of G. S. I. (1971); the contents of nitrogen, phosphorus and potassium in plants according to the method of B. A. Yagodin (1987); a record of forage crops harvest by the method of hand-harvesting, with subsequent conversion to the standard moisture content and purity by the method of G. S. I. (1971); analysis of fodder units output (Pustovoy V. I., 1995). 
In soil samples were determined: soil moisture by the gravimetric method (B. A. Dospekhov, 1987); soil pH in water suspension, State standard - GOST 26423 - 85; humus - by Tyurin in modification of Central Institute of Agrochemical Service, State standard - GOST 26213 - 91; nitrate nitrogen according to the method of Grandvall'age, GOST 26488 - 91; mobile phosphorus and exchangeable potassium according to the method of Machigin in the modification of Central Institute of Agrochemical Service, GOST 26205 - 91; nonexchangeable potassium according to the method of K. K. Giedroyz, water soluble potassium in water extract at the ratio of soil and water 1:5, gross potassium by the decomposition of soil hydrofluoric acid (Mineev, 2001).

\section{The results of the research}

We have found that the greatest amount of nitrate nitrogen in the control variant in the soil layer of 0-20 cm was noted after emergence of corn sprouts, which decreased with the increase of the vegetative mass till the phase of milky-wax ripeness. With the increasing of nitrogen consumption by plants the amount of nitrates in the soil decreased and reached its minimum in the phase of milky-wax ripeness (Figure 1).

In the soil at the fertilized variants the nitrate content was maximum at the beginning of the growing season, as well as in the control. Then the dynamic passed similarly to controls. All fertilizers significantly increased the content of nitrate nitrogen in the soil during the growing season of corn, and the difference with the control was in the phase of germination and $9.6-19.0 \mathrm{mg} / \mathrm{kg}$; in the phase of 5-7 leaves - 9,0-17,8 $\mathrm{mg} / \mathrm{kg}$; in the paniculation stage $-8,3-17,9 \mathrm{mg} / \mathrm{kg}$; in the phase of milky-wax ripeness $-8,4-16,3 \mathrm{mg} / \mathrm{kg}$.

The maximum content of nitrates in the soil in all phases of the development of maize was observed in the variants with the estimated fertilizer system that is associated with the highest saturation of this system with nitrogen fertilizer compared to other systems. In all the studied phases of corn development the bio-indicators of the system were higher than the recommended, but were inferior to the values of the estimated system ${ }^{1}$.
The maximum amount of mobile phosphorus in soil for corn silage in the control was observed in the early growing season $(21.1 \mathrm{mg} / \mathrm{kg})$, then it gradually decreased, reaching a minimum to the phase of milky-wax ripeness $(18,5 \mathrm{mg} / \mathrm{kg})$ (Figure 2).

Fertilized variants on the dynamics of mobile phosphorus did not differ from the control. In the first period of vegetation, the phosphates were intensively consumed by plants. To the harvest time the content of mobile phosphorus decreased.

All fertilized variants according to the supply of phosphorus were superior to the control in the phase of germination on $9.4-17.1 \mathrm{mg} / \mathrm{kg}$; in the phase of 5-7 leaves on $8.4-17,1 \mathrm{mg} / \mathrm{kg}$; in the paniculation phase on $6.5-14.4 \mathrm{mg} / \mathrm{kg}$, in the phase of milky-wax ripeness on $3.1-11.7 \mathrm{mg} / \mathrm{kg}$.

The highest content of phosphorus during the growing season was observed in the variants with the estimated fertilizer system, due to the optimal saturation with mineral fertilizers.

Dynamics of the content of exchange potassium in the $0-20 \mathrm{~cm}$ layer of soil under maize in the control decreased from the phase of seedlings to the phase of milky-wax ripeness. The fertilized variants showed the similar pattern (Figure 3).

The maximum content of exchangeable potassium on the average during the years of a research was observed in the phase of germination and ranged from $245 \mathrm{mg} / \mathrm{kg}$ soil in the control to 278 $\mathrm{mg} / \mathrm{kg}$ on the estimated fertilizer systems. Fertilized variants surpassed the control on the content of exchange potassium in the soil during the whole vegetation period of the culture. Thus, in the phase of 5-7 leaves on the content of exchange potassium in the soil, the fertilized variants surpassed the control variant on 9-32 $\mathrm{mg} / \mathrm{kg}$ in the paniculation phase - on $10-31 \mathrm{mg} / \mathrm{kg}$, in the phase of milky-wax ripeness - on $13-31 \mathrm{mg} / \mathrm{kg}$.

The highest content of exchangeable potassium over the years of a research has provided by the estimated fertilizer systems, which exceed the value not only of a control, but also the similar rates of other systems of fertilizers ${ }^{3}$. 
The potassium content in the soil in a greater degree depends not only on soil conditions but also on the time of year, moisture content, degree requirements of crops and has different intensities of transition from inaccessible forms in the exchangeable and water-soluble, that are available for plants.

The gross content of potassium in soils can vary greatly and depends mainly on the composition of minerals and soil-forming processes and their particle size distribution.

On the absorption capacity of the soil in relation to potassium is strongly influenced by soil moisture content, humus content, reaction environment, the absorption capacity and the degree of saturation of the bases, biological activity of soils, as well as the dose and form of potassium fertilizer ${ }^{2}$.

The content of mobile forms of potassium in the investigated variants was significantly changed, and the intraprofile differentiation of their distribution was quite significant. Regardless of the background of nutrition in the soil layer of $0-40 \mathrm{~cm}$ was observed weak differentiation of total potassium, in soil, 61$100 \mathrm{~cm}$, the content of total potassium decreased (table.1). Was observed a steady and insignificant increase in the content of total potassium in the soil layer of $11-20 \mathrm{~cm}$ compared with the control, which increase depending on the fertilization systems was 0.01 to $0.03 \%$. Distribution patterns for soil layers of non hydrolyzable potassium were similar to the distribution of total potassium. At the same time, the content of non hydrolyzable potassium in the soil layer of $0-10 \mathrm{~cm}$ at the recommended and biologizing systems fertilizers was less than 13-49 $\mathrm{mg} / 100 \mathrm{~g}$ of soil compared to the control. We found a trend of increasing of hydrolyzable potassium on the recommended, biologizing and estimated fertilizer systems, and the difference with the control in the studied layers were $(\mathrm{mg} / 100 \mathrm{~g}$ soil): $0-10 \mathrm{~cm}-1,7$ 5,$4 ; 11-20 \mathrm{~cm}-0.3$, and $8.7 \mathrm{mg} / 100 \mathrm{~g}$ of soil. A large increase not only with respect to the control, but also in options with the use of recommended and biologizing fertilizers systems provided the estimated fertilizer system².
According to the results of variance analysis all fertilizer systems contributed to a significant increase in the concentration of exchangeable potassium. Therefore, the analysis of secondary data, according to our experience, has shown that the recommended fertilizers exceeded the control by 9.7 ; biologizing - by 15.5 and estimated by $30.7 \mathrm{mg} / \mathrm{kg}$ of soil exchangeable potassium. The concentrations of exchangeable potassium on the estimated system significantly exceeded not only the control but also the values of the recommended and biologizing systems of fertilizers - by 21.0 and $15.2 \mathrm{mg} / \mathrm{kg}$ soil, respectively. In turn, the difference between parameters of exchangeable potassium of biologizing and the recommended fertilizers systems were within the NDS and consisted of $5.75 \mathrm{mg} / \mathrm{kg}$ of soil.

In recent studies of V. S. Tskhovrebov, it was shown that potassium is fixed by soil in the very first day of its application. This value consisted of $33-80 \%$ of the control for different types of soil, and during the year the amount of fixed potassium was varied slightly. In the soil remained the original ratio of potassium, inherent for that soil 6 .

A statistical processing of the data found that the maximum content of exchangeable potassium was observed in the soil layer of 11-20 $\mathrm{cm}$, which was $252.1 \mathrm{bln} \mathrm{mg/kg}$ of soil and was significantly higher than the average values in soil layers of $0-10 \mathrm{~cm}$ and $21-40-6.0$ and $21.4 \mathrm{mg} / \mathrm{kg}$ of soil, respectively. This is due to the optimum content in the soil layer of $11-20 \mathrm{~cm}$ of available moisture, and with location on this depth of the main mass of deposited fertilizer.

The main reason for the deterioration of the availability of potassium in plants is not an absolute reduction in its amount, but the weakening of the ability of a soil to maintain its original state, to recover the potassium content in available form ${ }^{5}$.

The amount of potash reserves in the soil that is potentially available to plants varies widely from $300 \mathrm{mg} \mathrm{K} 2 \mathrm{O} / \mathrm{kg}$ in sandy soils up to $3000 \mathrm{mg} /$ $\mathrm{kg}$ and more in chernozemic (humus) soils ${ }^{4}$. 
The highest content of exchangeable potassium was observed in the phase of germination of corn plants and amounted to $256,2 \mathrm{mg} / \mathrm{kg}$ of soil. Later during the growing season was a steady decrease in the content of this element in the soil. Moreover, in the interphase periods the seedlings of 5-7 leaves and 5-7 leaves-paniculation, there was a significant reduction in the concentration of exchangeable potassium (10.7 and $7.8 \mathrm{mg} / \mathrm{kg}$ soil), from the paniculation phase till the milky-wax ripeness was observed an insignificant reduction of the element (5.3 $\mathrm{mg} / \mathrm{kg}$ soil).
This is due to the frequency of consumption of potassium by maize plants: the interphase periods of seedlings-5-7 leaves and 5-7 leaves - paniculation, were corresponded to the most intense period of growth and development of culture, and, consequently, to the period of the maximum absorption of potassium.

All applied fertilizer systems in each development phase depending on the soil provided a significant increase in the potassium exchange content in the studied profile of leached chernozem (humus).

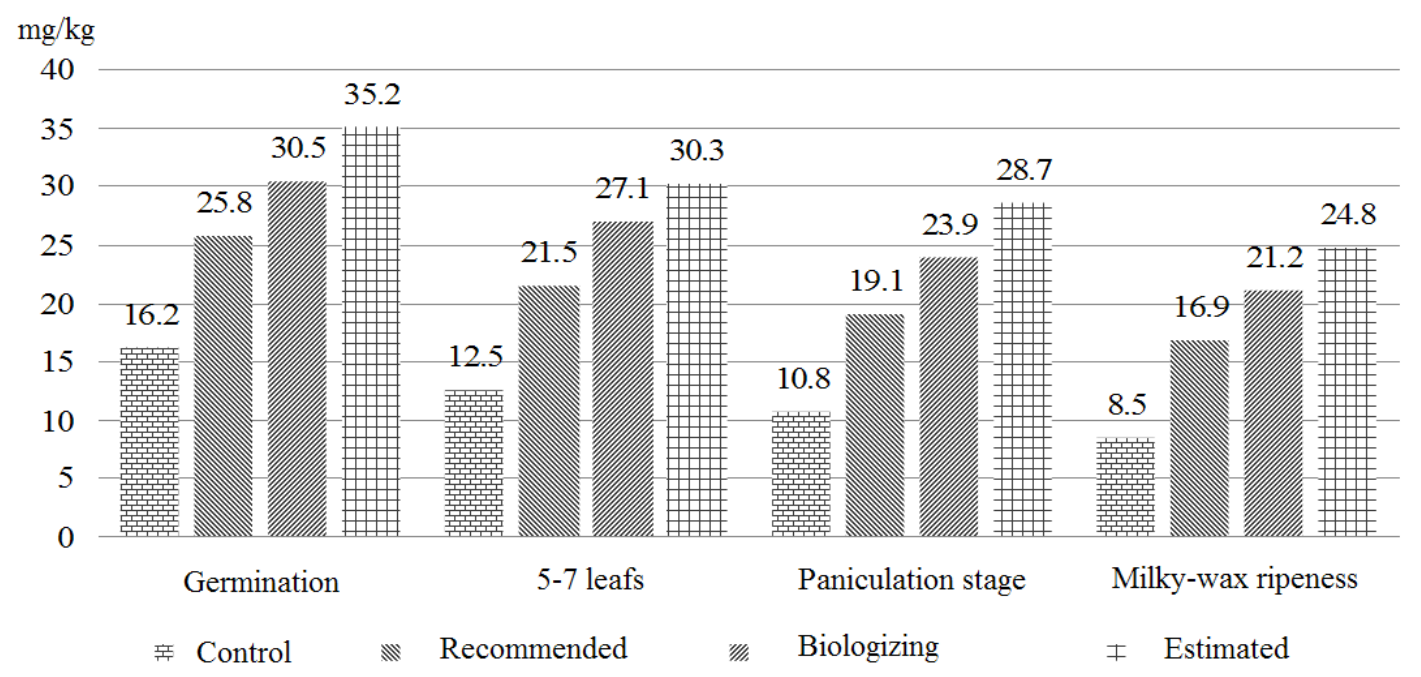

Fig. 1: Influence of fertilizer systems on the dynamics of the content of nitrate nitrogen in $\mathbf{0 - 2 0} \mathrm{cm}$ of soil layer

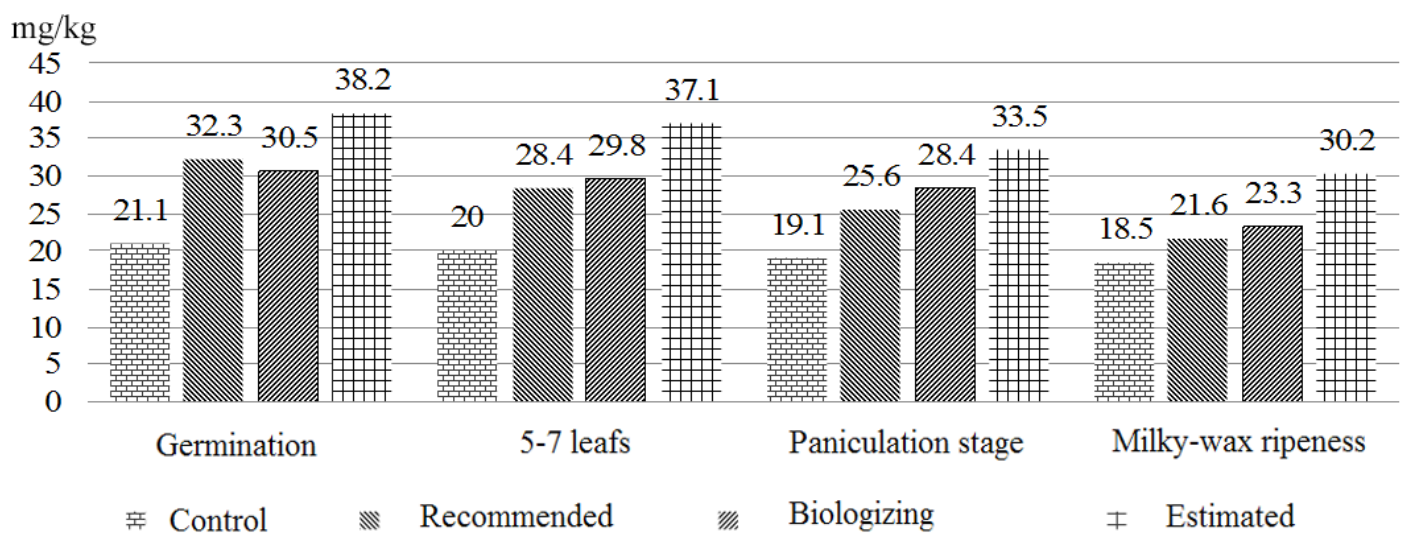

Fig. 2: Influence of fertilizer systems on the dynamics of mobile phosphorus content in the $\mathbf{0 - 2 0} \mathrm{cm}$ of soil layer 
Table 1: Influence of fertilizer systems on the dynamics of the content of potassium forms in the one-metre soil profile

\begin{tabular}{|c|c|c|c|c|c|}
\hline $\begin{array}{l}\text { Fertilizer systems, } \\
\text { saturation in crop } \\
\text { rotation NPK (kg/ha) } \\
\text { +manure (t/ha), }\end{array}$ & $\begin{array}{l}\text { Soil } \\
\text { layer, } \\
\text { cm, }\end{array}$ & $\begin{array}{c}\text { Gross, } \\
\%\end{array}$ & $\begin{array}{l}\text { Potassiu } \\
\text { non } \\
\text { hydrolyzable }\end{array}$ & $\begin{array}{c}\text { m form, mg/100 } \\
\text { hydrolyzable } \\
10 \% \mathrm{HCl}\end{array}$ & $\begin{array}{c}\text { g of soil } \\
\text { mobile }\end{array}$ \\
\hline \multirow[t]{6}{*}{ Control } & $0-10$ & 2,25 & 2049 & 103,5 & 25,1 \\
\hline & $11-20$ & 2,22 & 2040 & 110,2 & 25,3 \\
\hline & $21-40$ & 2,18 & 2012 & 114,6 & 24,3 \\
\hline & $41-60$ & 2,12 & 1987 & 111,3 & 22,1 \\
\hline & $61-80$ & 1,98 & 1952 & 98,2 & 21,1 \\
\hline & $81-100$ & 1,93 & 1884 & 97,1 & 19,3 \\
\hline Recommended $60+2,5$ & $0-10$ & 2,21 & 2036 & 105,2 & 26,7 \\
\hline (1978-1993 у.)115+5,0 & $11-20$ & 2,23 & 2052 & 110,5 & 26,6 \\
\hline \multirow[t]{4}{*}{ (2000-2004 y.) } & $21-40$ & 2,16 & 2007 & 115,8 & 24,9 \\
\hline & $41-60$ & 2,14 & 2002 & 107,8 & 23,3 \\
\hline & $61-80$ & 1,96 & 1943 & 107,1 & 21,4 \\
\hline & $81-100$ & 1,94 & 1899 & 98,0 & 19,9 \\
\hline Balance120+5 & $0-10$ & 2,16 & 2000 & 106,7 & 27,8 \\
\hline (1978-1993 y.) & $11-20$ & 2,24 & 2061 & 115,7 & 28,1 \\
\hline Biologizing $62,5+8,2$ & $21-40$ & 2,10 & 2008 & 108,1 & 25,7 \\
\hline \multirow[t]{3}{*}{ (2000-2004 y.) } & $41-60$ & 2,10 & 2016 & 104,2 & 23,2 \\
\hline & $61-80$ & 1,91 & 1897 & 105,1 & 21,1 \\
\hline & $81-100$ & 1,93 & 1918 & 96,1 & 20,0 \\
\hline The estimated180+7,5 & $0-10$ & 2,29 & 2091 & 108,9 & 29,7 \\
\hline (1978-1993 у.)167+5,0 & $11-20$ & 2,24 & 2013 & 118,9 & 29,1 \\
\hline \multirow[t]{4}{*}{$(2000-2004$ y.) } & $21-40$ & 2,15 & 2001 & 105,1 & 25,8 \\
\hline & $41-60$ & 2,08 & 1981 & 100,0 & 24,7 \\
\hline & $61-80$ & 1,99 & 1965 & 99,1 & 22,3 \\
\hline & $81-100$ & 1,94 & 1909 & 96,3 & 20,7 \\
\hline
\end{tabular}

Table 2: Influence of fertilizer systems on the dynamics of nitrogen content in the maize plants for silage, \%

\begin{tabular}{lcccc}
\hline $\begin{array}{l}\text { Fertilization } \\
\text { program }\end{array}$ & $\mathbf{5 - 7}$ leafs & $\begin{array}{c}\text { Paniculation } \\
\text { stage }\end{array}$ & The corb & $\begin{array}{c}\text { Milky-wax ripeness } \\
\text { Leaf-stalk mass }\end{array}$ \\
\hline Control & 3,00 & 1,59 & 1,56 & 0,52 \\
Recommended & 3,25 & 1,75 & 1,68 & 0,62 \\
Biologizing & 3,16 & 1,69 & 1,64 & 0,59 \\
Estimated & 3,36 & 1,85 & 1,77 & 0,66 \\
IÑ $_{0,5}$ & 0,14 & 0,08 & 0,07 & 0,09 \\
$\mathrm{Sx} \%$ & 2,8 & 3,2 & 3,7 & 4,0 \\
\hline
\end{tabular}


During all phases of the growing season the maximum content of exchangeable potassium in each soil layer was provided by the estimated system of fertilizers, which exceeded not only the indicators of the control, but the other fertilizer systems.

On a control variant till the paniculation stage, the consumption of exchangeable potassium by maize plant was in all the studied horizons. Further, the primary nutritional source was a soil layer of $21-40 \mathrm{~cm}$

With the recommended system of fertilizers from the phase of seedlings to the phase of 5-7 leaves the exchangeable potassium was mostly consumed from the layers of $0-10 \mathrm{~cm}$ and $21-40 \mathrm{~cm}$, to the phase of milky-wax ripeness the nutrition of plants was due to potassium consumption from soil layers.
On the system of bio-fertilizers till the paniculation stage, all the layers provided corn with exchangeable potassium, later the layers of 11-20 $\mathrm{cm}$ and $21-40 \mathrm{~cm}$ were the source of consumption. The recommended fertilizer till the phase of 5-7 leaves supplied corn with the exchangeable potassium due to the topsoil. Till the phase of milky-wax ripeness, the focus of consumption of the exchangeable potassium shifted in the layers 11-20 $\mathrm{cm}$ and $21-40 \mathrm{~cm}$. Layer-by-layer consumption of the exchangeable potassium from the studied profile $(0-40 \mathrm{~cm})$ of leached humus was predetermined by the moisture conditions and soil supply in mobile forms of potassium ${ }^{7}$.

With the strengthening of mineral nutrition the content of NPK in plants increases. On average over the three years of investigation, we have observed the following pattern: regardless of the variant of the experiment, in process of growth and

Table 3: Influence of fertilizer systems on the dynamics of phosphorus content in the maize plants for silage, $\%$

\begin{tabular}{lcccc}
\hline $\begin{array}{l}\text { Fertilization } \\
\text { program }\end{array}$ & $\begin{array}{c}\mathbf{5 - 7} \\
\text { leafs }\end{array}$ & $\begin{array}{c}\text { Paniculation } \\
\text { stage }\end{array}$ & $\begin{array}{c}\text { Vegetation phase } \\
\text { Milky-wax ripeness } \\
\text { The corb }\end{array}$ & Leaf-stalk mass \\
\hline Control & 0,63 & 0,34 & 0,49 & 0,25 \\
Recommended & 0,67 & 0,38 & 0,56 & 0,28 \\
Biologizing & 0,65 & 0,35 & 0,51 & 0,25 \\
Estimated & 0,69 & 0,41 & 0,58 & 0,32 \\
ÍÑ ${ }_{0,5}$ & 0,03 & 0,02 & 0,03 & 0,02 \\
Sx, \% & 4,3 & 3,9 & 4,7 & 3,6 \\
\hline
\end{tabular}

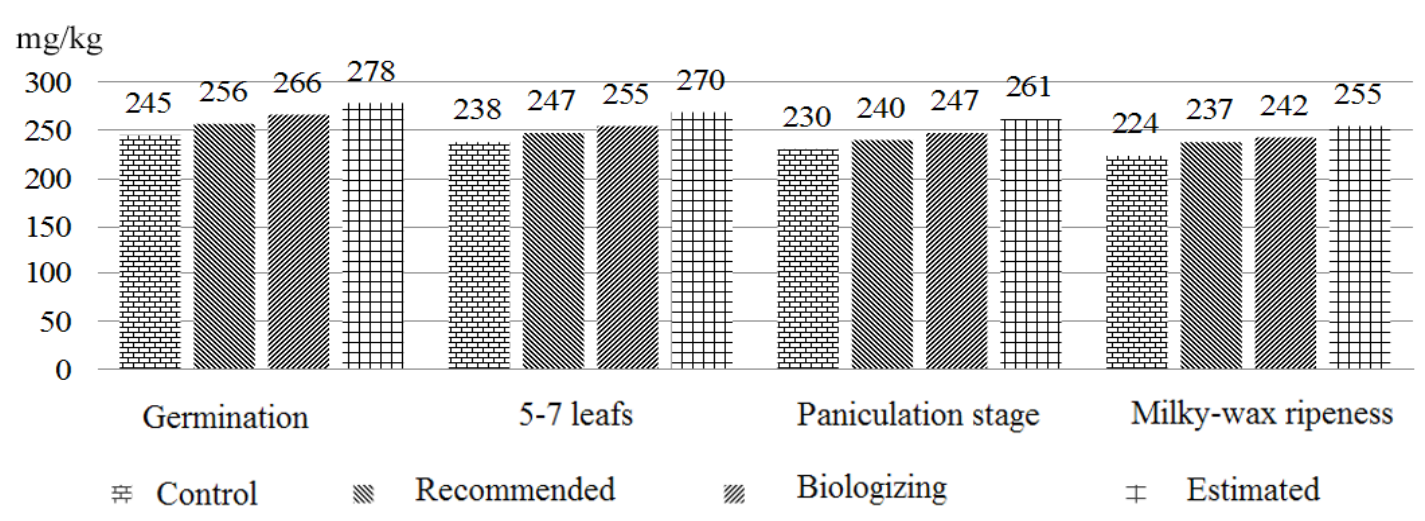

Fig. 3: Influence of fertilizer systems on the dynamics of potassium exchange content in $\mathbf{0 - 2 0} \mathrm{cm}$ of soil layer 
the development of maize plants, the content of NPK in plants was decreased. All of the studied fertilizer systems had a positive effect on the chemical composition of plants. Thus, the content of nitrogen in the maize plants in the variants with recommended fertilizers exceeded the control seedling stage by $0.25 \%$, the paniculation - by $0,16 \%$, milky-wax ripeness - by $0.12 \%$ (on the cob) and $0.1 \%$ (leafstem mass). Options with bio-fertilizer system slightly decreased that figure compared to the recommended system of fertilizer, but significantly higher than the control (table. 2).

The maximum effect on the accumulation of nitrogen in the maize plants had the use of the estimated system of fertilizers, which had increased the numbers in phases: germination- by $0.36 \%$, paniculation - by 0.26 , milky-wax ripeness - by 0,21\% (corn cob) and 0.14\% (leaf-stem mass).
It should be noted that the difference in the concentrations of nitrogen in plants to the time of harvesting of ripe corn between the studied variants was not significant and was within the error of the experiment that can be explained by a "dilution effect" by the concentrations of the element to a greater vegetative mass ${ }^{6}$.

Phosphorus in plants was less accumulated compare to the nitrogen, though its maximum content was also observed in phase of germination with a further decline by the end of the growing season. The studied fertilizer systems compared to the control had increased a phosphorus content ( \% ) in cons in a phase of 5-7 leaves - by 0,02-0,06; in the paniculation phase - by 0,01-0,04; in the phase of milky-wax ripeness - by $0,02-0,07$; of potassium in a phase of 5-7 leaves - by $0.09-0,36$; in the paniculation phase - by $0,04-0,11$; in the phase of milky-wax ripeness - by $0,02-0,12$. The maximum

Table 4: Influence of fertilizers systems on the dynamics of potassium content in maize plants for silage, $\%$

\begin{tabular}{lcccc}
\hline $\begin{array}{l}\text { Fertilization } \\
\text { program }\end{array}$ & $\begin{array}{c}\mathbf{5 - 7} \\
\text { leafs }\end{array}$ & $\begin{array}{c}\text { Vegetation phase of corn } \\
\text { Paniculation } \\
\text { stage }\end{array}$ & $\begin{array}{c}\text { Milky-wax ripeness } \\
\text { The corb }\end{array}$ & $\begin{array}{c}\text { Leaf-stalk } \\
\text { mass }\end{array}$ \\
\hline Control & 4,34 & 1,94 & 0,29 & 1,54 \\
Recommended & 4,44 & 1,98 & 0,31 & 1,57 \\
Biologizing & 4,43 & 2,02 & 0,32 & 1,59 \\
Estimated & 4,70 & 2,05 & 0,41 & 1,65 \\
íñ & 0,11 & 0,07 & 0,01 & 0,10 \\
Sx, \% & 2,2 & 2,8 & 3,5 & 4,6 \\
\hline
\end{tabular}

Table 5: The influence of fertilizer system on the average yield on silage

\begin{tabular}{lcccc}
\hline $\begin{array}{l}\text { System of } \\
\text { fertilizers }\end{array}$ & First & $\begin{array}{c}\text { Years of study } \\
\text { Second }\end{array}$ & Third & $\begin{array}{c}\text { The average } \\
\text { yield, c/ha }\end{array}$ \\
\hline Control & 330 & 360 & 339 & 343 \\
Recommended & 375 & 410 & 385 & 390 \\
Biologizing & 366 & 400 & 375 & 380 \\
Estimated $_{\text {HCP }}$, c/ha & 395 & 480 & 451 & 442 \\
Sx, \% & 8,9 & 22,0 & 17,0 & 21,5 \\
\hline
\end{tabular}


contents of nutrients in the maize plants were due to the estimated system of fertilizers (table. 3).

Dynamics of potassium content in plants, which data are presented in table 4 indicates a steady decline in the values of $\hat{E}_{2}$ I from early to the late phases.

The difference between unfertilized and fertilized variants was maintained until the phase of milky-wax ripeness, where a significant difference between the studied variants was still observed, whereas in the leaf-stem mass the values of potassium content was not significantly different from the control, except the estimated fertilizer system, which indicators exceeded the control by $0.11 \%$, because of the peculiarities of mineral nutrition of corn, which are highly demanding the potassium nutrition.

All fertilizers compared to the control had increased the content of potassium in maize plants in a phase of 5-7 leaves - by 0.09-0,36; in the phase of its emergence - by $0,04-0,11$; in the phase of milky-wax ripeness - by $0,02-0,12 \%$.

Application of fertilizers influenced the content of NPK in maize plants significantly increasing the performance in the phase of germination and flowering of cobs. The most effective in this regard was the estimated fertilizer system, providing the maximum content of NPK in plants ${ }^{3}$.

Application of fertilizers helped to increase the yield of green mass of corn for $47-99 \mathrm{~kg} / \mathrm{ha}$, with the least significant difference of $21.5 \mathrm{dt} / \mathrm{ha}$.

The smallest, but a significant increase in corn yield was obtained in variants with bio-fertilizers system - $37 \mathrm{~kg} / \mathrm{ha}$, higher than the control by $11 \%$.

The most effective was the estimated fertilizer system. The yield increase in these options relative to the control was $99 \mathrm{~kg} / \mathrm{ha}$, relative to the recommended and biologizing fertilizer system - 52 and $62 \mathrm{t} / \mathrm{ha}$, respectively. The difference in yield between the recommended and biologizing fertilizer system was insignificant and amounted to $10 \mathrm{~kg} /$ ha.
According to the three-year researches on leached humus without fertilizer the average yield of corn silage was $343 \mathrm{~kg} / \mathrm{ha}$ (table. 5).

Fertilizer application for corn silage in nonirrigated conditions on leached humus significantly increases the yield of green mass of corn per unit area, and the most effective in this respect, the estimated fertilizer system (manure $20 \mathrm{t} / \mathrm{ha}+$ $\mathrm{N}_{60} \bigoplus_{80} \hat{\mathrm{E}}_{30}+\mathrm{N}_{10} \bigoplus_{10}$ at sowing).

\section{DISCUSSION}

When growing for corn silage in conditions with moderate humidity in a production environment it is recommended:

1. On leached humus in the Central Caucasus the optimal dose of the basic fertilizer for corn crops for silage is manure $20 \mathrm{t} / \mathrm{ha}+\mathrm{N}_{60} \bigoplus_{80} \hat{\mathrm{E}}_{30}+\mathrm{N}_{10} \bigoplus_{10}$ (at sowing) in the estimated fertilizer system in crop rotation. In order to optimize the indicators of soil fertility it is recommended as a part of low-cost biosystem of fertilizers the use of manure $20 \mathrm{t} / \mathrm{ha}$ and adding at sowing $\mathrm{N}_{10} \bigoplus_{10}$

2. Depending on the nutrition background it is offered in the production the doses of nitrogen-potassium fertilizers $\mathrm{N}_{21} \hat{\mathrm{E}}_{21}$ and $\mathrm{N}_{42} \hat{\mathrm{E}}_{42}$ during the conduction of the 1st inter-row cultivation of maize for silage, providing increase of productivity of green mass by $38-53 \mathrm{~kg} / \mathrm{ha}$.

\section{CONCLUSION}

1. All studied fertilizer system during the growing season of maize increased the content of major nutrients in the soil. $0-20 \mathrm{~cm}$ and the difference with the control was $(\mathrm{mg} / \mathrm{kg})$ : with nitrate nitrogen - the phase of germination - 9.6-19,0, phase of 5-7 leaves - 9,0-17,8, the phase of the buttonhole $-8,3-17,9$, the phase of milky-wax ripeness - 8,4-16,3; with mobile phosphorus - sprout phase - 9.417,1 , phase of $5-7$ leaves $-8,4-17,1$, phase of the buttonhole is $6.5-14.4 \mathrm{~V}$, the phase of milky-wax ripeness - 3,1-11,7; exchangeable potassium - the phase of 5-7 leaves is 9-32, the phase of the buttonhole - 10-31, the phase of milky-wax ripeness - 13-31. The highest content of nutrition elements in the 
soil in all stages of development of maize was observed in the variants with application of an estimated fertilizer system.

2. Thirty-year application of fertilizers had no significant influence on the content of studied in layers of the meter profile of leached gross humus, of hydrolyzable and non- hydrolyzable potassium. On the fertilized variants with respect to the natural agrochemical background are insignificant (1,3-7,1 mg/100 g soil) decreased indicators of hydrolysis of potassium in the soil layers of 21-40, 41-60 and $81-100 \mathrm{~cm}$. The fertilizer system had significantly increased the content of mobile potassium and the difference relative to the control in the soil was $(\mathrm{mg} / 100$ g soil): 0-10 cm - 1,6-4,6; 11-20 cm - 1,3-3,8; 21-40 cm - 0,6-2,4; 41-60 cm - 1,1-2,6; 61 to $80 \mathrm{~cm}-0,1-1,3$ and $81-100 \mathrm{~cm}-0,6-1,4$. Maximum values of the content of mobile potassium provided an estimated fertilizer system.

According to the results of variance analysis all fertilizer systems had contributed to a significant increase in the concentration of exchangeable potassium and the difference of average values of the experiment was $10-31 \mathrm{mg} / \mathrm{kg}$ of soil. The maximum content of exchangeable potassium was observed in the soil layer of $11-20 \mathrm{~cm} 230-288 \mathrm{mg} / \mathrm{kg}$.
3. Dynamics of the content of major nutrients in plants regardless of the nutrition background had a single course reduction during the growing season of maize. The fertilizer system compared to the control had increased in maize plants the content of (\%):total nitrogen - in a phase of 5-7 leaves - 0,16-0,36; in the paniculation phase - on $0,1-0,26$; in the phase of milky-wax ripeness - on 0,08-0,21; phosphorus - in a phase of 5-7 leaves - on $0,02-0,06$; in the paniculation phase - on 0,01 0,04 ; in the phase of milky-wax ripeness - on $0,02-0,07$; potassium in a phase of 5-7 leaves - on 0.09-0,36; in the paniculation phase - on $0,04-0,11$; in the phase of milky-wax ripeness - on 0.02 and 0.12 . The maximum contents of nutrients in the maize plants provided the estimated fertilizer system.

4. Analysis of variance determined that significant yield increase was provided by all the studied fertilizer system and the difference with control was $52-99 \mathrm{~kg} / \mathrm{ha}$. The most effective was the estimated fertilizer system with adding directly under the culture of $20 \mathrm{t} / \mathrm{ha}$ of manure $+\mathrm{N}_{60} \bigoplus_{80} \hat{E}_{30}+\mathrm{N}_{10} \bigoplus_{10}$ (at sowing), which provided the yield of green mass of corn silage- $442 \mathrm{~kg} / \mathrm{ha}$. Difference in yield between the recommended and biologizing systems of fertilizer was not significant.

\section{REFERENCES}

1. Grechishkina, Y. I. Dynamics of potassium exchange in common Chernozem. Fertility, 2007, 3, 59-61.

2. Korostylev, S. A. The influence of systems of fertilizers on the content of different forms of potassium, a food mode of leached humus and productivity of silage corn: dis. K. S. H. B. SSAU, Stavropol, 2008.

3. Prokoshev, V.V. The Relevance of agrochemical studies of the potassium status of soils in the geographic network of experiments with. Improving the organization and methodology of agrochemical research in the Geographical network experiments with fertilizers: materials of all-Russian scientific-methodical conference Geographical network experiments with fertilizers, 17-20 Oct. 2005. Moscow, 2006,. 34-36.

4. Slyusarev, V. N.; Onischenko, L. M.; Shvets, T. V. Soil-ecological evaluation of the West foot Caucasus leached Chernozem. Polythematic network electronic scientific journal of the Kuban state agrarian University, Kuban state agrarian University, 2013, 89, 960-972.

5. Tskhovrebov V. S. Changes in soil-forming process in the black soil of the Caucasus in the conditions of agrocenosis. Proc. scientific. articles on materials of the IV mezhdunar. scientific. Conf. Stavropol, 2015,. 62-66.

6. Esaulko, À.N. Influence of fertilizers and methods of soil cultivation on the dynamics of mobail sulphur chernozem leached to the 
winter wheat crops in the zone of an unreliable moistening of Stavropol territory. Research journal of pharmaceutical, biological and chemical sciences, 2016, 7(3), 2578-2581.

7. Vlasova, O.I.; Perederieva, V.M.; Volters,
I.A.; Tivikov, A.I.; Trubacheva, L.V. Change in microbiological activity under the effect of biological factors of soil fertility in the central fore-caucasus chernozems. Biology and Medicine, 2015, 7 (5) BM-146-15, 6. 